\title{
From Strategic Litigation to Juridical Action
}

\author{
Andreas Fischer-Lescano
}

\begin{abstract}
With strategic litigation, lawyers and public interest NGOs have sought to bring socio-structural problems before courts around the world for many years. In doing so, they (a) initiate legally substantiated lawsuits that (b) pursue goals beyond a legal process' "success" and (c) address considerable political issues. Litigation strategists often strive to realise the judicial enforcement of human rights, environmental rights, trade union rights, migrant and refugee rights, and so on, in these proceedings. In other words, they seek to make the law "better." It is precisely here that legal mobilisation's structural limitations - also present in the day-to-day business of law-come to light in the context of strategic litigation.
\end{abstract}

Keywords Deconstruction - Collective rights - Critical theory · Juridical action · Legal subjects $\cdot$ Paradoxes of law $\cdot$ Poststructuralism $\cdot$ Representation $\cdot$ Strategic litigation $\cdot$ Violence

\section{Critique of Strategic Litigation}

The concept of strategic litigation ${ }^{1}$ comprises a strangely narrow approach. The term "litigation" reflects that the law is part of the social crisis to be addressed. However, focusing on litigation as an answer to the crisis and using courts as forums for protest $^{2}$ entails the danger of underestimating non-legal forums' importance for the legal process and, at the same time, overestimating state institutions and courts' role in legal battles. In relation to the concept of property, Katharina Pistor asserts that "[a]sset holders do not need to capture the state directly, much less win class

\footnotetext{
${ }^{1}$ For an overview see: Baxi (1985); Duffy (2018); see further the definition by Graser (2019a), p. 4. ${ }^{2}$ Lobel (2003).
}

\author{
A. Fischer-Lescano (ه) \\ Universität Bremen, Bremen, Germany \\ e-mail: sekretariat-voelkerrecht@uni-bremen.de
}


struggles or revolutions; all they need is the right lawyers on their side who code their assets in law." 3 This criticism of state institutions equally applies to strategic litigation, which often begins too late, addresses ineffective forums and reduces critical legal policy disputes to court battles. ${ }^{4}$ Counterforces are too seldom positioned where needed ${ }^{5}$ - in legislation, economic and trade circles, or universities and schools. At the same time, litigation strategists risk losing sight of potential allies outside of state forums, who also articulate very clear criticisms of the law and even imitate the law's procedural forms, such as social courts in the tradition of the Russell Tribunals and Milo Rau's Congo Tribunal. ${ }^{6}$

The adjective "strategic" with which litigation activists describe their practice is regularly used either in a trivial sense-all litigation could be classified as "strategic" after all, as nearly all decisions about legal proceedings are made with clear goals, based on rational reasoning regarding how to achieve them-or the protagonists overestimate strategic litigation's foreseeability, underestimating the fact that its unpredictability is a central element of the legal process. As Adam Weiss rightly observes, a process' strategic consequences often cannot be anticipated, only evaluated retrospectively, ${ }^{7}$ which of course raises the question of what criteria should be used for this evaluation. Answering this question often abruptly leads into a circle of self-righteousness. Litigation strategists measure their "success" against their strategy concept, which they adjust over the course of the process. This way, of course, even the most brutal judicial defeats can be glossed over as successfully implemented strategies to expose a class of law or force moments of public awareness of legal loopholes. Regardless of a court case's outcome, these "legal miracles" confirm all parties' legal opinions. This is possible due to vaguely formulated strategies.

If, however, strategic litigation is discontent with formulating short-term public relations and fundraising strategies and instead wants to initiate social transformation, it will have to develop sustainable goal-setting connected to other social spheres and movements. Today, the field lacks critically-reflected strategy formation. Empirical studies about strategic litigators' strategic behaviour have only just begun, but their mission statements, content and introductory remarks on strategic litigation ${ }^{8}$

\footnotetext{
${ }^{3}$ Pistor (2019), p. 22.

${ }^{4}$ Roberto M. Unger's demand that the legally-supported democratisation of society should also apply to the economy and civil society is also critical of this. See Unger (1996), p. 164.

${ }^{5}$ If they are, they are often side-lined by strategic litigation, in which lynchpin social contact points are usually the concrete processes and legal relationships-whether in law clinic trainings, litigation-related NGO alliances, fundraising with interested members of the public, or by cooperating with the press in reporting on trials.

${ }^{6}$ Klinghoffer and Klinghoffer (2002) and Rau (2017).

${ }^{7}$ Weiss (2019), p. 30: "Anyone who tells you he is litigating a strategic case right now is wrong: it is impossible to know in advance if a case will prove to have been strategic or not, because unpredictability is a key element."

${ }^{8}$ See Fuchs (2019).
} 
make it more than clear that conceptual strategy development problems arise that reduce strategic litigation's effectiveness in fighting injustice.

\subsection{Lack of Ambition}

Strategic litigation is rarely ambitious enough. It seldom questions the system in which it participates, frequently abstains from partisanship in favour of those affected, and often fails to articulate the injustice of the social order. As a result, it has a stabilising effect on the prevailing political and juridical system. As Christian Helmrich puts it: "Behind strategic litigation is belief in the existing system. There is nothing subversive about strategic litigation." 9 Strategic lawsuits against public participation (SLAPPs) ${ }^{10}$ are thus not a hostile hijacking of a form of protest. Instead, they represent the flip side of an ambivalent practice that is not primarily concerned with changing the system, but with stabilising it. The mission statement of the Berlin-based NGO Gesellschaft für Freiheitsrechte (GFF) is "Our strategy: Better law through better lawsuits." "11 "Freedom" (Freiheit) in the NGO's name becomes a "signifier of (practical, political, but also theoretical) disorientation" for such litigation strategists. ${ }^{12}$

Anyone who limits themselves to making "better" law in order "to protect human and civil rights in Germany and Europe" ${ }^{" 13}$ runs the risk that the defence of civil liberties "produces, reproduces and sediments the exact opposite of freedom, namely a lack of freedom." A strategic concentration on civil rights in constitutional law in Germany and Europe inevitably leads to Eurocentric narrow-mindedness. Consequently, case selection is oriented towards European interests or handled in such a way that transnational issues of exploitation, environmental pollution and threats to peace can be addressed in European courts. The cross-border character of structural societal problems, the transnationality of social questions, and the hybrid publicprivate quality of surveillance measures all fall through the cracks. ${ }^{15}$ In the defence

\footnotetext{
${ }^{9}$ Helmrich (2019a), p. 34.- Translation by the author.

${ }^{10}$ Pring and Canan (1996).

${ }^{11}$ Gesellschaft für Freiheitsrechte, Mission Statement 2019, www.freiheitsrechte.org/strategischeklagen (last accessed 17 July 2019).-Translation by the author.

${ }^{12}$ Ruda (2018), p. 8.-Translation by the author.

${ }^{13}$ See the self-description of the Gesellschaft für Freiheitsrechte, Mission Statement 2019, www. freiheitsrechte.org (last accessed 17 July 2019).

${ }^{14}$ Ruda (2018), p. 8.-Translation by the author.

${ }^{15}$ See, for example, GFF's reasoning for an amicus curiae brief in the Microsoft v. United States, 2nd US Circuit Court of Appeals, No. 14-2985, which it supported, leaving completely unmentioned that Microsoft itself is a data wholesaler and thus a human rights abuser: "GFF is submitting the amicus curiae brief in order to demonstrate how the forthcoming decision could have an unacceptable indirect impact on federal and European law guarantees. In principle, it therefore supports the arguments presented by Microsoft in the proceedings." (GFF, Amicus Curiae Brief
} 
of liberty's pathos-GFF claims to "strengthen civil and human rights against state intrusion" 16 - it is lost that there is no existing freedom in society to be defended, as freedom can only be established in the fight against existing unfreedom.

Strategic litigation demands strategy formation through analysing the social situation at hand. It must not follow legal education's apolitical stagnant structure. ${ }^{17}$ In order to bring about lasting change, procedural strategies and targets must be strategically reflected upon, especially in order to incorporate legal procedures' limitations. In this sense, Gayatri Spivak criticises juridical action's inadequate strategies as being potentially effective in the short term but, at best, only capable of accompanying rather than causing long-term change: "My principal argument continues to be that a combination of fear and pressure, today supported by these powerful paradisciplinary formations proliferating crude theories of cultural difference, cannot bring about either lasting or real epistemic change although, accompanied by public interest litigation, they may be effective short-term weapons." 18

\subsection{Depoliticisation}

At the same time, strategic litigation often has a depoliticising tendency, despite legal processes' scandalising potential. This is due to proceedings' respective constellation. "Subjective rights," the core of Christoph Menke's apt criticism, ${ }^{19}$ privatise the public sphere, which, in turn, forces litigation strategists to enforce rights with private means when it is actually socio-structural questions that need negotiation. ${ }^{20}$ This can certainly be a suitable transformation strategy, as long as one reflects on how poorly the legal form mirrors the underlying socio-structural conditions and

U.S. Supreme Court, 19 January 2018, www.freiheitsrechte.org (last accessed 17 July 2019)). And GFF's dutiful thanks to the business law firm White \& Case: "The amicus curiae brief was prepared by GFF with the support of the international law firm White \& Case. They did this work pro bono, for which GFF would like to express its sincere thanks."-Translations by the author. This deliberately leaves unmentioned that White \& Case's portfolio includes the representation of the high-tech giants Facebook, Google, PayPal, Avast Software etc. In view of the conflicting interests of this large law firm, which works closely with companies that endanger human rights themselves, from which GFF claims to protect them (and us), the "pro bono" seal is probably awarded somewhat lightly (for the White \& Case portfolio, see www.whitecase.com/law/industries/ technology\#experience (last accessed 17 July 2019).

${ }^{16}$ GFF, Mission Statement 2019, www.freiheitsrechte.org (last accessed 17 July 2019).—Translation by the author.

${ }^{17}$ On the desiderata of socially responsible legal education and the failure of educational reforms, see Wiethölter (1981).

${ }^{18}$ Spivak (2004), p. 540.

${ }^{19}$ Menke (2015), p. 173.

${ }^{20}$ Ingeborg Maus criticises an "infantilism of faith in justice," over the course of which political activity is replaced by legalistic strategies to implement social justice and environmental protection "in the hope that these goods will be allocated by the highest court." See Maus (2018), p. 27. 
conflicts, and how little the real social conflict (différend) is reformulated in the legal process (litige). As Jean-François Lyotard puts it, the différend does justice to the litige; however, the litige can never do justice to the différend. ${ }^{21}$ Participants often lack necessary awareness of the obstacles and alienation effects of "the individualistically conceived planks into which (procedural) law usually forces strategic litigation." 22

In the worst-case scenario, protagonists negate legal practice's political content, for example, when, in concession to the establishment, they appease others' demands: $:^{23}$ "In our understanding, the objection that we politicised the legal system through our legal interventions is therefore also mistaken." ${ }^{24}$ Instead of emphasising all law and jurisprudence's political momentum, one withdraws to technocratic legalism. The politicisation argument is rejected with reference to a purely legal approach, because one is only trying to "draw the judges' attention towards questions that are decisive from a fundamental and human rights perspective." 25 As if there were a right life in the wrong (Theodor Adorno), this makes the lie of apolitical law its own. Litigation strategists swim in "circles, empty phrases, alibis and taboos." ${ }^{26}$ Hence, it is necessary to make clear the political aspect of law and its most significant expression: the prevailing view. ${ }^{27}$ Without a political theory of law for the presence of a political society that "understands" how we are entangled in an outdated "legal culture," we will not reach the height of our time, but will freeze in the depths of prehistoric times.

\subsection{Advocatory Violence}

In the context of strategic litigation, there is often insufficient awareness of the danger of advocatory violence, particularly the danger that lawyers come to control

\footnotetext{
${ }^{21}$ Lyotard (1989), p. 9; see also Lyotard (2004), p. 43, on the contradiction (différend) as a sentence that cannot be articulated, but as an "affect sentence," always irreconcilably opposed to the legal dispute (litige). As a discourse sentence, it is never identical to the legal reformulation: "[The] articulated sentence and [the] affect sentence can only 'meet' each other by missing each other."

${ }^{22}$ Helmrich (2019b), p. 140.-Translation by author.

${ }^{23}$ The latter, for example, opposes strategic climate litigation with the argument that it ultimately weakens the judiciary itself, because social problems' juridification through court decisions "will meet with considerable political and social resistance." The "real political un-achievability of the reduction targets of the IPCC [Intergovernmental Panel on Climate Change] and other climate protection bodies" is asserted, and a concept of legitimacy that would do justice to the problem's transnational character is not developed at all (quotes by Wegener (2019), p. 12; critical of such objections: Graser (2019b), p. 271).

${ }^{24}$ Burghardt and Thönnes (2019), p. 68.-Translation by the author.

${ }^{25}$ Burghardt and Thönnes (2019), p. 68.-Translation by the author.

${ }^{26}$ Wiethölter (1986), p. 10.- Translation by the author.

${ }^{27}$ For classic arguments on this topic, see Wesel (1979), p. 88.
} 
the narrative instead of their clients. Especially in transnational advocacy constellations, individual and collective interests rarely coincide. ${ }^{28}$ The interests of the victims of the 2012 Ali Enterprises factory fire in Pakistan ${ }^{29}$ are not necessarily identical with that of European NGOs wanting to create awareness of ongoing colonialism and illegalities in transnational supply chains. ${ }^{30}$ And even if one has to give credit to the European Center for Constitutional and Human Rights (ECCHR) for the fact that in the Ali Enterprises and Rana Plaza cases it has in fact formed alliances "of workers, affectees associations and local unions along with international relief, campaign and human rights organizations," ${ }^{31}$ which is unprecedented in German legal practice and transnational in the best sense of the word, representation of the unrepresented always remains precarious.

When litigation strategists call for goal-setting with "all stakeholders involved,"32 exclusion mechanisms are surely at work. In strategic corporate management it may be positive to extend the focus to all stakeholders rather than the usual concentration on shareholders. ${ }^{33}$ However, the division of the legal-political world into "stakes" and "holders" inevitably leads to exclusionary situations for diffuse interests ${ }^{34}$ and those who have no voice. ${ }^{35}$ Various problems derive from this, including: (a) the fixation on legitimate interests, their owners and the legally enforceable (subjective) law as an instrument to solve social problems, which is a deeply European idea; (b) the fact that other models of social organisation and conflict resolution regularly fall out of sight due to this fixation; and (c) in the relationship between the helping NGOs and those affected, the danger of a colonial power dynamic (white saviour complex) is often immanent. ${ }^{36}$ Litigation, if practised nevertheless, must reflect on these dangers and enact effective safeguards so that power asymmetries are not reproduced and deepened.

\footnotetext{
${ }^{28}$ A rule of doubt can only be a first move in dissolution. See Kessler and Borkamp (2019).

${ }^{29}$ See 7 O 95/15 Landgericht Dortmund judgment on 10 January 2019.

${ }^{30}$ Saage-Maaß and Terwindt (2020).

${ }^{31}$ ECCHR, Week of Justice, 4 November 2018, www.ecchr.eu/en/event/one-week-of-justice (last accessed 17 July 2019).

${ }^{32}$ Lindner (2019), p. 99.

${ }^{33}$ See Freeman (2010).

${ }^{34}$ On the difficulty of translating these into law: Kommer (2012).

${ }^{35}$ This is where Boaventura de Sousa Santos (2012), p. 52, comes in when he calls for a "Sociology of Absences:" "By sociology of absences I mean research that aims to show that what does not exist is actually actively produced as non-existent, that is to say, as an unbelievable alternative to what exists. Its empirical object is impossible from the point of view of conventional social sciences. Impossible objects must be turned into possible objects, absent objects into present objects."

${ }^{36}$ Do Mar Castro Varela and Dhawan (2015), p. 87.
} 


\subsection{Victimological Defensiveness}

Finally, litigation strategies are quite often characterised by what we might call "victimological defensiveness," for example, when strategic litigation's main goal is "to limit interventions, especially on the part of the state, and to support affected social actors in mobilizing the law." 37 The fact that the aim should be to empower those affected from passive "victims" to become agents of transformation and enable social change in legal processes, which must lead to transformed economic power relations, in particular, is not given enough consideration in a merely defensively oriented legal position against "interventions." This is especially so if one takes a liberalist approach in the traditional sense and wants to counter "interventions, especially on the part of the state." Such approaches only reproduce the liberal misunderstanding of separation of state and society, of public and private. They insufficiently address the equally threatening dangers emanating from non-state spheres, while their destructive and self-rationality-maximising expansions into political and social processes (keyword: "market-conforming democracy") threaten the autonomy of political and social processes. ${ }^{38}$ In other words, primarily statedirected legal strategies will not go far in addressing responsibility for inhumane and ecologically devastating global supply chains, the deaths of migrants and asylumseekers in the Mediterranean, big data's effects, or the damage caused by a globalised financial market.

\section{Juridical Action}

In response to deconstructive legal criticism in the US, numerous parties have repeatedly emphasised that it is necessary to practice individual legal defence, rupture defence and strategic litigation "nonetheless." 39 This is not wrong, because legal struggles are dependent on established forms, but it should not be used as a pretext to consider strategic litigation in its existing form as immutable. A sustainable transformation of the legal form and the social structures that underpin it can only be achieved by a transformative legal policy of reflected anticipation: "It anticipates the other law counterfactually in the existing one. It is political fiction (or of the imagination)."

In this view, strategic litigation's practices are rarely imaginative enough. They must therefore be transformed, for example, based on the 1923 legal mobilisation strategy developed by Karl Korsch, co-founder of the German Institute for Social Research, in the context of labour law. His concept of "juridical action" (juristische

\footnotetext{
${ }^{37}$ Burghardt and Thönnes (2019), p. 66.-Translation by the author.

${ }^{38}$ Fischer-Lescano (2016b).

${ }^{39}$ For a prominent example, see Williams (1987).

${ }^{40}$ Menke (2018), p. 30.- Translation by the author.
} 
Aktion) does not dispense with strategic considerations, but seeks to take into account the unplannable, spontaneous, contingent and irrational in order to ultimately bring "chaos into order." 41 Korsch opposes "business as usual" (das Weiterso) and distinguishes between two concrete steps in juridical action. First and foremost, he suggests that the points should be determined at which a conflict has already flared up or is currently in the process of flaring up between civil law and social law conceptions of the employment relationship. Second, an attempt must then be made at each of these individual points to deduce the consequences of the social-law viewpoint in a way that corresponds, as explicitly as possible, to the present historical situation. ${ }^{42}$ This double movement of juridical action need not necessarily lead to litigation. What is central, however, is that (1) the analytical dimension involving the description of the conflict or paradox and (2) the activist conclusion of deducing consequences in a way that explicitly corresponds to the specific historical situation, are coordinated. ${ }^{43}$ These two concrete steps constitute juridical action.

\subsection{First Step}

Juridical action's first step is to identify hidden, veiled and invisible paradoxes. One must name the social abyss, not cover it up. That the law is permeated by contradictions, ruptures and paradoxes is not a new idea, but has been central to (legal) philosophy since Heraclitus. This is expressed in Gustav Radbruch's “antinomies of the idea of law" just as much as in Jean-François Lyotard's concept of "contradiction," Jacques Rancière's “incomprehension,” Jacques Derrida's “aporia,” Ernesto Laclau and Chantal Mouffe's "dialectic," Amy Allen, Wendy Brown and Christoph Menke's reference to the "paradoxons" and Rudolf Wiethölter's famous "Factor X.",44

Karl Marx's critique of Georg Wilhelm Friedrich Hegel's theory of the state also focuses on real contradictions and distinguishes true from vulgar critique, precisely by whether the former is able to do what the latter does not: grasp the necessity of the contradiction.

Vulgar critique falls into [...] dogmatic error. For example, it criticizes the constitution. It draws attention to contradiction of powers, etc. It finds inconsistencies everywhere. This is still dogmatic critique that struggles with its subject matter, just as, for example, the dogma of the Holy Trinity was once eliminated by the contradiction of one and three. True critique, on the other hand, shows the Holy Trinity's inner genius in the human brain. It describes its birth. Thus, the true philosophical critique of the present state constitution does not only

\footnotetext{
${ }^{41}$ With reference to Adorno: Wiethölter (1994), p. 107.

${ }^{42}$ Korsch (1980), p. 392.

${ }^{43}$ Seifert (2013).

${ }^{44}$ Wiethölter (1988).
} 
show contradictions exist, it explains them, and understands their genesis, their necessity. It grasps their unique meaning. ${ }^{45}$

Such true legal critique, which opens up the possibility for contingency and transcendence, is "not simply a political or legal critique," 46 but is embedded in social theory. It reconstructs the "distinctions of the natives" 47 and captures these structures' essential contradictions to explain the failure of traditional distinctions as well as create space for contingencies. A systemic critique in the name of the paradox of right and wrong can never reach a conclusion. Critique in the name of Factor $\mathrm{X}$, in the name of justice, or in the name of deconstruction is a thorn in the flesh, a formula for searching instead of a yardstick.

\subsection{Second Step}

Juridical action, however, must not be exhausted in the theoretical posture of radical criticality; it must also take a second step, that of turning the identified contradiction into a contradiction against reality. It must actively work to tear up systemic contradictions $^{48}$ and use social forms against their own formal logics. Juridical action is a theoretical-practical form of action that "transfers" systemic forms into new, more just forms. It is a practice of form transcendence.

\subsubsection{Legal Action Against the Far Right}

The most important task of our time is to name all forms of soft and hard authoritarianism, ${ }^{49}$ to reject right-wing legal nihilism ${ }^{50}$ and right-wing nihilistic extremism, and to fight "rightlessness in an age of rights" would include radical juridical action on issues like the totalitarian synchronization (Gleichschaltung) of the judiciary in Hungary, Poland and Turkey; institutional racism; the criminalisation in France of critical analysis of the political bias of judges

\footnotetext{
${ }^{45}$ Marx (2006), p. 296.-Translation by the author.

${ }^{46}$ See Michel Foucault's critique of juridicism in: Foucault (2018), p. 341.

${ }^{47}$ Luhmann (1993), p. 256.

${ }^{48}$ See objective formulation: Christodoulidis (2009), p. 25: "Forcing [the legal system] to confront a contradiction."

${ }^{49}$ For different forms of authoritarianism, see: Randeria (2019).

${ }^{50}$ Of frightening topicality, see Adorno's 1967 lecture in Adorno (2019); for more on right-wing strategies to abolish the rule of law with the means of the rule of law, see Kleinschmidt (2016), p. 169.

${ }^{51}$ Gündogdu (2015).

${ }^{52}$ Baer (2019).
} 
in asylum cases (Platform Supra Legem) ${ }^{53}$ the proclamation of "Get-out" (Hau-Ab) laws in Germany; and the declaration of states of emergency and armed assaults in response to terrorist attacks.

\subsubsection{Decentralisation}

Further, it is necessary to reflect on postcolonial critiques in order to overcome the law's Eurocentrism and imperial life's externalisation of costs: to "act as if another globalization were possible." 54 For this, Wiethölter suggests that not only Europe, but also the "subject of reason" must be decentralised and removed from its essential position in law. Instead of allowing the legal status relationship to merge into statecitizen relations, social rights must be formulated that do not conceive of interventions in merely statist logic. In other words, what is needed are new, non-rational legal entities (like animals, cyborgs and body fragments), new forms of organisation for social dissidence (from labour law to science law, tenancy law, environmental law and financial market law), ${ }^{55}$ and new patterns of obligation (like human rights obligations of private individuals).

\subsection{3 "Manufacturing” Law}

In addition, one needs to fundamentally question the "distribution" of rights and prosperity through the development of novel patterns of allocation. As Wiethölter puts it, "right/freedom as freedom/right (right-fabrication!)" 56 is needed to radically address the question of property that is posed daily in the face of global inequality. This would seek not only to increase social ties and limit abuse, but would start with the use of property itself: to limit the concept of property itself, to oppose other rights, ${ }^{57}$ and to legally address the postmodern class question as a question of "distribution of distribution" 58 in different functional contexts by developing new counter-rights that break up the traditional patterns of distributional allocation. ${ }^{59}$ Derrida formulates it as "inventing new rights. Even if these new rights always remain inappropriate to what I call justice. A justice that is not law, even if it is to determine its history and progress."60

\footnotetext{
${ }^{53}$ Langford and Rask Madsen, France Criminalises Research on Judges, VerfBlog, 22 June 2019, www.verfassungsblog.de (last accessed 17 July 2019).

${ }^{54} \mathrm{Rau}$ (2019), p. 26.

${ }^{55}$ Hensel (2019).

${ }^{56}$ Wiethölter (1986), p. 61, author's emphasis.

${ }^{57}$ See plea, still topical today, in: Ridder (1977).

${ }^{58}$ Luhmann (1985), p. 119.

${ }^{59}$ Loick (2018).

${ }^{60}$ Derrida (1998).
} 


\subsubsection{Culture of Dispute}

Finally, it is central to end the complicity of human and civil rights movements as well as litigation strategists in the liberal human rights discourse. In Wiethölter's words, successor organisations need to be developed "for the - now permanently sussed out - loss of 'law' as a neutral (impartial) third party, which originally as God or nature, and later as order, market and freedom, promised a world of just 'allocations' and 'distributions,' but was not able to keep that promise."61 While we certainly need to safeguard social spheres of freedom from state intervention, we do not need more enforcement of alleged achievements of European constitutionalism in liberalistic excesses in the forms of World Bank development programmes and US-American interventionism. ${ }^{62}$ Our focus should lie on legal safeguards for the process of social democratisation. Here the challenge lies, as Spivak has rightly pointed out, in suturing "the habits of democracy onto the earlier cultural formation [...] the real effort should be to access and activate the tribals' indigenous 'democratic' structures to parliamentary democracy by patient and sustained efforts to learn to learn from below." ${ }^{63}$ The task of law as a culture of dispute is then to enable this kind of subaltern appropriation of law, the legal organisation of democratic processes not only within the framework of parliamentary representation, but also within the framework of social forms of democracy. Law as a "culture of dispute" enables democratic debate in the respective social contexts. ${ }^{64}$

\section{Conclusion: Juridical Action as a Strategy of Dissidence}

Juridical action worthy of the name takes into account litigation's inadequacies and clarifies strategy before initiating any "strategic litigation." Juridical action de-centres the legal process by taking it seriously as a crystallisation point of social disputes, but is aware of the falseness of the litige. In this knowledge and despite all reservations, it uses the legal process as a forum for conflict staging, articulation and transformation, ${ }^{65}$ but only to immediately transcend the legal process' limitations. Thus, juridical action transcends the legal system to incorporate politics, the arts, science, literature, theatre and economics. It eludes categorical functional differentiations. Like Franz Kafka's legal criticism, Peter Weiss's theatrical interpretation of the Auschwitz trial and Karl Kraus' cursing of procedure, ${ }^{66}$ juridical action seeks to

\footnotetext{
${ }^{61}$ Wiethölter (1986), p. 62.- Translation by the author.

${ }^{62}$ So do Slaughter and Jackson (2019).

${ }^{63}$ Spivak (2004), p. 548.

${ }^{64}$ In this sense, also Kaleck (2019).

${ }^{65}$ See also Trüstedt (2012).

${ }^{66}$ Weiss (1991); on Kraus, see Trüstedt (2016); on Kafka's legal criticism, see Fischer-Lescano (2016a).
} 
disrupt and to confront injustice. As an action critical of order (contre-conduite), ${ }^{67}$ it is important for juridical action to increase the "rejection points" in the political fabric and expand the area of possible dissent.

\section{References}

Adorno T (2019) Aspekte des neuen Rechtsradikalismus. Suhrkamp, Berlin

Baer S (2019) Democracy in peril: a call for amici and amicae curiae and critical lawyering. Transnatl Leg Theory 10(2):140-162

Baxi U (1985) Taking suffering seriously: social action litigation in the Supreme Court of India. Third World Leg Stud 4:107-132

Burghardt B, Thönnes C (2019) Die Gesellschaft für Freiheitsrechte. In: Graser A, Helmrich C (eds) Strategic Litigation. Begriff und Praxis. Nomos, Baden-Baden, pp 65-72

Christodoulidis E (2009) Strategies of rupture. Law Crit 20(1):3-26

De Sousa Santos B (2012) Public sphere and epistemologies of the south. Afr Dev 37(1):43-67

Derrida J (1998) I distrust utopia, I want the impossible. DIE ZEIT, 5 March 1998

Do Mar Castro Varela M, Dhawan N (2015) Postkoloniale Theorie. Transscript, Bielefeld

Duffy H (2018) Strategic human rights litigation: understanding and maximising impact. Hart, London

Fischer-Lescano A (2016a) Franz Kafka's critique of legal violence. Revista Brasileira de Sociologia do Direito 3:9-51

Fischer-Lescano A (2016b) Struggles for a global internet constitution. Protecting global communication structures against surveillance measures. Global Constitutionalism 5(2):145-172

Foucault M (2017) Sicherheit, Territorium, Bevölkerung. Geschichte der Gouvernementalität. Suhrkamp, Berlin

Foucault M (2018) Die Geburt der Biopolitik. Suhrkamp, Berlin

Freeman E (2010) Strategic management: a stakeholder approach. Cambridge University Press, Cambridge

Fuchs G (2019) Rechtsmobilisierung. In: Boulanger et al (eds) Interdisziplinäre Rechtsforschung. Springer, Wiesbaden, pp 243-256

Graser A (2019a) Was es über Strategic Litigation zu schreiben gälte. In: Graser A, Helmrich C (eds) Strategic Litigation. Begriff und Praxis. Nomos, Baden-Baden, pp 9-19

Graser A (2019b) Vermeintliche Fesseln der Demokratie: Warum die Klimaklagen ein vielversprechender Weg sind. Zeitschrift für Umweltrecht 2019(5):271-278

Gündogdu A (2015) Rightlessness in an age of rights: Hannah Arendt and the contemporary struggles of migrants. Oxford University Press, Oxford

Helmrich C (2019a) Wir wissen eigentlich gar nicht, was strategische Prozessführung ist. In: Graser A, Helmrich C (eds) Strategic Litigation. Begriff und Praxis. Nomos, Baden-Baden, pp 31-35

Helmrich C (2019b) Strategic Litigation rund um die Welt. In: Graser A, Helmrich C (eds) Strategic Litigation. Begriff und Praxis. Nomos, Baden-Baden, pp 115-140

Hensel I (2019) Wissenschaftskampfrecht. Kritische Justiz 52(4):449-478

Kaleck W (2019) Mit Recht gegen die Macht. In: Graser A, Helmrich C (eds) Strategic Litigation. Begriff und Praxis. Nomos, Baden-Baden, pp 21-26

Kessler A, Borkamp U (2019) JUMEN e.V. In: Graser A, Helmrich C (eds) Strategic Litigation. Begriff und Praxis. Nomos, Baden-Baden, pp 73-80

\footnotetext{
${ }^{67}$ Foucault (2017), p. 292.
} 
Kleinschmidt R (2016) Fallstudie: Die Rechte und das Recht. In: Braun et al (eds) Strategien der extremen Rechten. Springer, Wiesbaden, pp 167-195

Klinghoffer AJ, Klinghoffer JA (2002) International citizens' tribunals: mobilizing public opinion to advance human rights. Palgrave, Basingstoke

Kommer S (2012) Diffuse Umweltrechte in Brasilien. Zeitschrift für Umweltrecht 23(9):459-468

Korsch K (1980) Arbeitsrecht für Betriebsräte (1922). In: Buckmiller M (ed) Karl Korsch Gesamtausgabe. Europäische Verlagsanstalt, Frankfurt am Main, pp 279-492

Lindner C (2019) Strategic Litigation zwischen Wissenschaft, Lehre und anwaltlicher Praxis. In: Graser A, Helmrich C (eds) Strategic Litigation. Begriff und Praxis. Nomos, Baden-Baden, pp 91-102

Lobel J (2003) Success without victory: lost legal battles and the long road to justice in America. New York University Press, New York

Loick D (2018) Der Missbrauch des Eigentums. August Verlag, Berlin

Luhmann N (1985) Zum Begriff der sozialen Klasse. In: Luhmann N (ed) Soziale Differenzierung. Zur Geschichte einer Idee. Westdeutscher Verlag, Opladen, pp 119-162

Luhmann N (1993) "Was ist der Fall?" und "Was steckt dahinter?". Zeitschrift für Soziologie 22 (4):245-260

Lyotard JF (1989) Der Widerstreit. Wilhelm Fink, Munich

Lyotard JF (2004) Der Affekt-Satz. In: Lyotard JF (ed) Das Elend in der Philosophie. Passagen, Vienna, pp 41-49

Marx K (2006) Kritik des Hegelschen Staatsrechts. In: Marx Engels Werke. Dietz, Berlin, pp 203-333

Maus I (2018) Justiz als gesellschaftliches Über-Ich. Suhrkamp, Berlin

Menke C (2015) Kritik der Rechte. Suhrkamp, Berlin

Menke C (2018) Genealogie, Paradoxie, Transformation. In: Franzki et al (eds) Gegenrechte. Recht jenseits des Subjekts. Mohr-Siebeck, Tübingen, pp 13-31

Pistor K (2019) The code of capital. Princeton University Press, Princeton

Pring G, Canan P (1996) SLAPPs. Getting sued for speaking out. Temple University Press, Philadelphia

Randeria S (2019) Varieties of voice: ballot box, courts and streets. In: Meldolesi L, JaStame N (eds) A bias for hope. Italic Digital Editions, Rome, pp 226-240

Rau M (2017) Das Kongo Tribunal. Verbrecher Verlag, Berlin

Rau M (2019) Orestes in Mosul. Golden Book. Verbrecher Verlag, Berlin

Ridder H (1977) Der Grundrechtsschutz des Eigentums, seine Grenzen und Beschränkungen im Öffentlichen Interesse. In: Österreichische Juristenkommission (ed) Der Grundrechtsschutz des Eigentums. C.F. Müller, Heidelberg, pp 39-58

Ruda F (2018) Gegen-Freiheit. Komik und Fatalismus. Konstanz University Press, Konstanz

Saage-Maaß M, Terwindt C (2020) Recht der imperialen Lebensweise. In: Buckel et al (eds) Neue Theorien des Rechts. Mohr-Siebeck, Tübingen, pp 341-358

Seifert J (2013) Zum Stellenwert der juristischen Aktion bei Karl Korsch. In: Kritidis G (ed) Zur Aktualität von Karl Korsch und seine Bedeutung für die Entwicklung der sozialistischen Linken. Loccumer Initiative kritischer Wissenschaftler und Wissenschaftlerinnen, Loccum, pp 3-8

Slaughter AM, Jackson A (2019) Afghanistans vergessene Frauen. Blätter für deutsche und internationale Politik 29(4):49-50

Spivak G (2004) Righting wrongs. South Atl Q 103(2-3):523-581

Trüstedt K (2012) Nomos and Narrative: Zu den Verfahren der Orestie. In: Ladeur et al (eds) Die Innenwelt der Außenwelt der Innenwelt des Rechts. Fink, Munich, pp 59-77

Trüstedt K (2016) Der Fluch des Verfahrens: Karl Kraus und die Akten zum Fall Kerr. Mod Lang Notes 131(3):701-723

Unger RM (1996) What should legal analysis become? Verso, London

Wegener B (2019) Urgenda. Weltrettung per Gerichtsbeschluss? Zeitschrift für Umweltrecht 30 (1):3-13 
Weiss P (1991) Die Ermittlung: Oratorium in 11 Gesängen. Suhrkamp, Frankfurt am Main

Weiss A (2019) The essence of strategic litigation. In: Graser A, Helmrich C (eds) Strategic

Litigation. Begriff und Praxis. Nomos, Baden-Baden, pp 27-30

Wesel U (1979) Herrschende Meinung. Kursbuch 56:88-109

Wiethölter R (1981) Reformatio in peius. Zur Geschichte der Ausbildungsreform. Ein Gespräch.

Kritische Justiz 14(1):1-17

Wiethölter R (1986) Rechtswissenschaft. Helbing und Lichterhahn, Basel

Wiethölter R (1988) Zum Fortbildungsrecht der (richterlichen) Rechtsfortbildung. Fragen eines lesenden Recht-Fertigungslehrers. Kritische Vierteljahresschrift für Gesetzgebung und Rechtswissenschaft 3(1):1-28

Wiethölter R (1994) Zur Argumentation im Recht: Entscheidungsfolgen als Rechtsgründe? In: Teubner (ed) Entscheidungenfolgen als Rechtsgründe: Folgenorientiertes Argumentieren in rechtsvergleichender Sicht. Nomos, Baden-Baden, pp 89-120

Williams PJ (1987) Alchemical notes: reconstructing ideals from deconstructed rights. Harv Civ Rights-Civ Liberties Law Rev 22(2):401-433

Andreas Fischer-Lescano is professor of public law, European law, international law and legal theory at the University of Bremen, Germany. He is director of the Center of European Law and Politics (ZERP) at the University of Bremen and co-editor of the journal Kritische Justiz. His research focuses on international law, human rights, European external relations and legal theory. He edited the book Neue Theorien des Rechts (third edition 2020, with Sonja Buckel and Ralph Christensen) and Contested Regime Collisions. Interdisciplinary Inquiries into Norm Fragmentation in World Society (Cambridge 2016, with Kerstin Blome et al.), and Recht gegen rechts. Report 2020 (Fischer-Taschenbuch 2020, with Nele Austermann et al.).

Open Access This chapter is licensed under the terms of the Creative Commons Attribution 4.0 International License (http://creativecommons.org/licenses/by/4.0/), which permits use, sharing, adaptation, distribution and reproduction in any medium or format, as long as you give appropriate credit to the original author(s) and the source, provide a link to the Creative Commons license and indicate if changes were made.

The images or other third party material in this chapter are included in the chapter's Creative Commons license, unless indicated otherwise in a credit line to the material. If material is not included in the chapter's Creative Commons license and your intended use is not permitted by statutory regulation or exceeds the permitted use, you will need to obtain permission directly from the copyright holder.

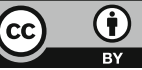

